\title{
COMPULSORY UNIONISM: A STRENGTH OR WEAKNESS? THE NEW ZEALAND SYSTEM COMPARED WITH UNION SECURITY AGREEMENTS IN GREAT BRITAIN AND IN THE UNITED STATES
}

\author{
ALEXANDER SZAKATS*
}

In the following article Doctor Szakats evaluates the workers' position with regard to the necessity of membership in a union as an indispensable prerequisite for obtaining and retaining work. In particular, he analyzes current employer-union practices and legislation in New Zealand, Great Britain and the United States. The author points out that in New Zealand the relevant statutes apply only to registered workers' associations. However, a registered union has the advantages of: a monopoly position; blanket clauses; and unqualified preference clauses. The author concludes that the so-called abolition of compulsory unionism in New Zealand does not change the position of workers seeking employment since by virtue of the unqualified preference clauses in nearly all awards and industrial agreements, compulsory unionism has de facto remained in force. In Great Britain, as in New Zealand, relevant statutes apply only to registered associations. Although it has been recognized in Great Britain since 1871 that trade unions are voluntary associations, the theory does not always conform with the practice. As a result, certain arrangements can inhibit a worker's choice of a specified trade union and closed shop agreements may lawfully counteract this right of not joining, thereby introducing a de facto compulsory unionism. By way of contrast to Great Britain and New Zealand, relevant legislation in the United States extends to and binds all trade unions. The author concludes that although compulsory unionism imposed by the state generally weakens the labour movement, compulsory unionism imposed by employer-union agreement strengthens the movement.

\section{INTRODUCTION}

Labour organizations have always and everywhere in the world had the aim to organize as many workers as possible, and to reach the greatest, if not one hundred per cent, membership. Their purpose is not only to increase the income from fees and dues, but more significantly and primarily, to represent the whole, or at least the majority, of the workers in the industry with which they are concerned, to achieve greater bargaining power, and in general, to improve the status of the union.

In the Nineteenth Century, and even in the first decades of the present one, trade unions fought for the very recognition of their right to exist, to function as lawful associations, to organize and represent the workers, and to be accepted as equals at wage negotiations. ${ }^{1}$ Their struggle brought success to such an extent that the pendulum swung to the other direction, and to say that their "cup overfloweth" would not be an exaggeration. While older workers may still remember the times when being a union member could mean the loss of the job, the younger ones have experienced the exact opposite: they had to belong to a trade union if they wanted to acquire and retain work. Freedom to associate, the right to join a trade union, mysteriously has been transformed into an obligation, and at the same time also into a prerequisite for employment. From the widespread use of closed shop agreements, other

- LL.B. (N.Z.), Dr. Pol. (Budapest), Dr. Iur., Reader in Commercial Law, Victoria University of Wellington, Barrister and Solicitor of the Supreme Court of New Zealand.

- In Britain trade unions achieved legal recognition by the Trade Unions Act, 1871; in the United States full freedom of association was declared by the Norris.La Guardia Act, 1932, and the unions' position was made atrong by the Wagner Act, 1935; in New Zealand unions existed on the English pattern before the enactment of the Industrial Conciliation and Arbitration Act, 1894, re-enacted in 1954 and amended many times. 
union security arrangements, preference clauses in collective agreements and awards, ${ }^{2}$ with a considerable assistance of legislation, the concept and practice of compulsory unionism has emerged.

As a reaction against this development the idea of protecting the individual against the immensely increased power of the trade unions has manifested itself in some legislative countermeasures endeavouring to assist the stubborn non-unionist in his determination to be left alone. The main objective, beside that of upholding on principle the negative freedom of association, appears to be the separation of trade union membership from what has become known as the "right to work."

The purpose of this article is more modest than an attempt to examine the entire field of labour law relating to the right to work in all its ramifications. The dual topic of importance, the right to initial admission into a trade union and its twin, the right to readmission after a purported expulsion, or more correctly the right of remaining a member unless expelled for a just reason after a lawful procedure, and the adverse consequences of losing-or not gaining-membership with regard to employment opportunities, will not form the leitmotif of the following discussion. ${ }^{3}$ The problem will be approached from the opposite direction: not as a right, but as a duty of becoming and remaining a trade union member, with the corresponding right, if there is one, to stay out as an unorganized worker but having the same job potential as a unionist. In this context the right to work is not parallel with, but juxtaposed to, trade union membership. Some of the questions relevant to the twin topics of admission and expulsion will, however, be touched, as they are equally connected with the problem of compulsion.

It is intended to focus the following analysis around the theme of compulsory unionism: first in New Zealand where this form of union organization goes back to the end of the last century, and has become an integral part of the industrial relations system based on compulsory conciliation and arbitration; secondly in Great Britain where the new Industrial Relations Act, $1971^{4}$ reaffirms the principle of voluntariness regarding union membership but permits certain forms of closed shop and agency shop agreements; thirdly in the United States where closed shop agreements are now, with some exceptions, prohibited but where union shop and agency shop agreements through the union hiring hall achieve very much the same results. ${ }^{5}$

\section{COMPULSORY UNIONISM IN NEW ZEALAND}

\section{The Significance of Registration}

Union security arrangements in New Zealand are closely connected with the conciliation and arbitration system, and particularly with the specific advantages granted to registered unions. Registration under the Industrial Conciliation and Arbitration Act, $1954^{6}$ is not compulsory but

2 This refers to New Zealand; see infra Part 1I, Compulsory Unionism in New Zealand.

3 See regarding these problems Lloyd, The Law of Associations in Law and Opinion in England in the Twentieth Century 99 (ed. M. Ginsberg); Lloyd, The Right to Work (1957) 10 Current Legal Problems 36; Rideout, The Right to Membership of a Trade Union in Grodin, Union Government and the Law.

4 Industrial Relations Act, 1971, c. 72, (hereinafter cited as "the I.R. Act").

5 The relationship between trade unions and non-organized workers poses many intriguing questions, and for a full comparative analysis the examination should be extended to some continental labour relations systems, mainly Germany, Italy and Sweden, and also to Canada and Australia; the narrow confines of the present article do not allow expansion, but the author intends to carry the theme further, and indeed, he is advancing in his research.

- Industrial Conciliation and Arbitration Act 1954 (No. II) (N.Z.), 8. 53 (hereinafter cited as "I.C. \& A. Act"). 
by the very act of registering, unions undertake certain obligations which are counterbalanced with some advantages. As it has frequently been said, registration is something of a package deal. It is for the workers' organization to decide whether or not the advantages offered outweigh the simultaneously imposed duties. ${ }^{7}$ The majority of unions obviously found the advantages worthwhile as very few unregistered workers' societies exist. ${ }^{8}$ Although there is nothing to prevent these societies from functioning as trade unions, and from carrying out organizing activities among a certain segment of the workers, when competing with a registered union they encounter a number of serious impediments.

The main advantages gained by registration, apart from the fact that the union becomes a corporate entity, can be summarized under three headings:

1. Monopoly position.

2. Blanket clause.

3. Unqualified preference clause.

\section{Monopoly Position}

Monopoly position means that where a workers' society is registered as an industrial union of workers, ${ }^{9}$ covering a certain industry in a defined industrial district, no other union can be registered in respect of the same industry in the same district except with the concurrence of the Minister of Labour. ${ }^{10} \mathrm{~A}$ union is prohibited from amending its Rules for the purpose of extending the circle of workers eligible for membership, ${ }^{11}$ and thereby reaching out for members in an industry where a registered trade union already exists. "Body-snatching" is not allowedunless the other workers' organization functions without registration, in which case its members are fair game. The unregistered union, however, may be strong enough to withstand any attack on its membership, its members may be sufficiently devoted to it, and as a result it may continue in existence, thereby making the monopoly position of the registered union illusory. The added disadvantages, notwithstanding inner strength, tend to make the position of unregistered societies fairly precarious. Consequently unions now functioning without registration have resulted from the voluntary decision of big organizations to take themselves out of the I.C. \& A. Act, and to retain an already established monopoly position.

\section{Blanket Clause}

The second advantage is the application of the blanket clause. The decision of the Arbitration Court concluding the process will be expressed in the form of an award which lays down the terms and conditions to be incorporated in the individual employment contracts. Notwithstanding that the arbitration proceedings are between two parties, the union and

\footnotetext{
7 The principal obligation is that all disputes must be settled through the conciliation and arbitration machinery within the four corners of the Act, and as a consequence strike will not be resorted to. Other duties relate to certain matters in the Rules, election of officers, accounts and audit.

8 The most significant ones are the Pulp and Paper Workers Union, the Chemical Fertilizer Workers' Union and the United Mine-Workers' Union.

- The I.C. \& A. Act refers to societies of workers which upon registration will become "industrial unions of workers" to distinguish them from industrial unions of employers: s. 53. In this article the word "union" never refers to employers' unions.

10 I.C. \& A. Act, s. 58(1).

" Except with the concurrence of the Minister: 8. 58(2); see N.Z. Engineering etc. I.U.W. v. Duncan [1971] N.Z.L.R. 818
} 
the employers' organization (or individual employer), the binding force of the award extends beyond the immediate parties. It is possible, and indeed usually it is the case, that certain employers do not belong to the employers' organization or for other reasons are not participating in the proceedings, thus prima facie the award would not apply to them. By virtue of inserting the blanket clause, besides the original and added parties, the award: ${ }^{12}$

... by force of this Act, shall extend to and bind as a subsequent party thereto every union, association or employer who, not being an original or added party thereto, is, when the award comes into force or at any time while it is in force, connected with or engaged in the industry to which the award applies within the locality to which the award for the time being relates.

An added party is any person or organization to whom the Court of Arbitration on the application of any of the original parties extends the operation of the award. ${ }^{13}$ Thus an added party is made into a party expressly by a separate Order of the Court. It is to be noted that the parties originally bound are not only the actual parties to the proceedings, the workers' union and the employers' union (or employers), but "every worker who is at any time while [the award] is in force employed by any employer on whom the award is binding." 14 A subsequent party, similarly without any further order of the Court, may be any union, association or employer, who is "connected with" or "engaged in" that particular industry when the award comes into force, or who will be so connected or engaged during any later time while the award remains in force. Thus the award, when it is made, has a binding force extending beyond the parties to the proceedings:

1. on individual workers employed at that time by any employer bound by the award, and

2. on unions, associations and individual employers not yet in existence.

"Not yet in existence" should not necessarily be interpreted literally, though with corporations that will be the case, but it means "not yet in existence in the industry" signifying that the contingent subsequent party has not yet commenced business in the industry. As soon as a new employer is engaged in the industry ${ }^{15}$ the award shall apply to him the same way as statutes and regulations do. It can be said that the award has a contingent binding force for the future.

The Court has power to exclude any union, association or employer from the application of the award, ${ }^{16}$ and may restrict it to specified employers.17 Any party bound as a subsequent party can apply to the Court for total or partial exemption from the award, and the Court may grant it unconditionally, or subject to conditions or may refuse to grant exemption. ${ }^{18}$

\section{Legislation by Private Contract}

A blanket clause in most awards is worded as follows:

This award shall apply to the original parties named herein, and shall extend to and bind as subsequent party hereto every industrial union, industrial association, or

12 I.C. \& A. Act, s. 154(1).

เ3 Id. 8. 160.

14 Id. 8. 153(1).

15 An employer must be engaged in the industry in order to be bound by an award. See Norman v. Inspector of Factories [1962] N.Z.L.R. 929.

16 I.C. \& A. Act, 8. 154(2).

12 Id. в. 155.

10 Id. 8. 154(3). 
employer who, not being an original party hereto, is, when this award comes into force or at any time whilst this award is in force, connected with or engaged in the industry to which this award applies within the industrial districts to which this award relates.

It is obvious that the operative words of the clause repeat those of section 154(1). The blanket application, the contingent future binding force of the award does not arise from the clause but from the statute itself. For this reason the insertion of the clause in awards can be regarded as absolutely unnecessary. ${ }^{19}$ Without the express provision of the Act any attempt by the parties, indeed even by the Court, to extend the application of the award to non-parties would have, and could have, no validity at all. Industrial agreements made by registered unions bind only the parties but further parties may join by filing a notice of concurrence. ${ }^{20}$ Furthermore, if the agreement is binding on employers who employ the majority of workers in the industry, and if it is not against the public good or in excess of the jurisdiction of the Court, the Court may declare it to be an award; ${ }^{21}$ this has, however, very rarely happened. The usual course is that when the parties settle their dispute through conciliation, they request the Court to incorporate the terms of settlement in an award and thereby gain the advantage of the blanket clause. The Court may do so without a hearing. ${ }^{22}$

As a result when the Court makes an award on the basis of the terms agreed to by the parties to the dispute an originally bilateral agreement will be elevated into a delegated legislative enactment with all the adherent public regulatory force. It has been settled long ago that an award is legislative authority in judicial form; ${ }^{23}$ but the transformation of an agreement into a set of rules with statutory value amounts to legislation by private contract, and a sub-delegation of legislative authority by the state. ${ }^{24}$

\section{Unqualified Preference: Historical Development}

The most significant union security device is the unqualified preference clause inserted in an award or industrial agreement. Before examining the effect of preference clauses on the workers seeking employment, as well as on employers, it seems necessary to outline briefly the legal and political development of the closed shop concept which culminated in what is commonly denoted as compulsory unionism.

Clauses purporting to create a closed shop were already inserted in awards and agreements during the first years of the I.C. \& A. Act, ${ }^{25}$ and unions endeavoured to obtain the employers' cooperation in pre-

10 See In Re N.Z. Carpenters etc. Award (1958) 58 Book of Awards 2089, (hereinafter cited as "Bk. Aw.").

20 I.C. \& A. Act, 8. 104. If the parties settle the dispute voluntarily the ensuing agreement will be registered with the Clerk of Awards as an industrial agreement, and becomes enforceable as such: s. 103.

21 Id. s. 108. See also 8. 107 which provides that the Arbitration Court may extend an industrial agreement to further parties without the consent of such parties; this procedure has never been used.

22 Id. 8. 130.

23 See N.Z. Waterside Workers' Federation I.A.W. v. Fraser [1924] N.Z.L.R. 689 at $708-9$ per Salmond J.: An award is . . a code of rules for the regulation of the industry concerned during the currency of the award ... determining not the present rights and obligations of litigants but the future relations and obligations of all persons who thereafter . . . choose to enter into contractual relations with each other as employers and employed....

24 See Ramm, The German Law of Collective Agreements in Labour Relations and the Law 84 at 90 (ed. Kahn.Freund), referring to German collective agreements which are considered to be private contracts but their terms have the force of statute; this is the "social autonomy" resulting from the delegation of legislative authority. In New Zealand bilateral private contracts can be made into public regulations only through the instrumentality of the Arbitration Court; thus by accepting the terms settled by the parties the Court in effect subdelegates its award making powers.

2s The statute was enacted in 1894, frequently amended, and reenacted in 1954; the present 1954 Act has also been amended many times. 
ferring union members. In 1896 the coal miners in the Denniston mines succeeded in securing a preference clause as follows: 26

That, as regards hewing coal and trucking and tipping, so long as there are sufficient capable men at Denniston out of work, the company shall employ these either by the contract or day-labour provided they are willing to work at reasonable rates, before the company calls for tenders from outsiders or employs outsiders.

Organized bootmakers also expressed unwillingness to work side by side with non-unionists, and their union achieved the inclusion of a more straightforward clause:27

Employers shall employ members of the New Zealand Federated Bootmakers' Union in preference to non-members, provided there are members of the union who are equally qualified with non-members to perform the particular work required to be done, and are ready and willing to undertake it....

A few years later a writ of prohibition was moved from the Supreme Court against the Judge ${ }^{28}$ and members of the Arbitration Court to prevent their including preference clauses in awards on the ground of lack of jurisdiction. The Supreme Court refused the writ, and the Court of Appeal confirmed the decision. ${ }^{29}$ It was held unanimously that the Arbitration Court may, in its discretion, include in any award an order that unionists shall have preference in employment over non-unionists, and that the Court of Appeal, or any other Court, has no control over the Arbitration Court in matters within its jurisdiction. Stout C.J. said:30

The Court [of arbitration] has, in my opinion, power to give preference to unionists, even though non-unionists are not heard by the Court, and not allowed to represent their case. The Court . . . can control the privileges of employers, and can fix the status of workmen, or the class of persons that can be employed.

Williams J. was even more emphatic: ${ }^{31}$

The non-unionist workman has no legal right to demand employment. He can sell his labour at what price and on what terms he chooses, provided he can find an employer able and willing to accept his terms; but he has no right to demand that there shall be an employer able and willing to accept his terms. The effect of giving preference to unionists is to place a restraint on the employer, and not to interfere with the rights of the non-unionists ... [who] never had a right to compel an employer to employ them, or to demand employment unconditionally ... [T]he interests of workers other than trade-unionists must be incidentally affected by the decisions of the Court; but that is inevitable if the Act is to have any operation at all.

\section{Judicial Rejection of "Conscription"}

Amendment to the Act reaffirmed the judicial interpretation of the Arbitration Court's jurisdiction by expressly including among "industrial matters" a new paragraph: "the claim of members of industrial unions of workers to be employed in preference to non-members." 32

It will be observed that the preference clauses examined did not aim to entirely exclude non-unionists from all employment for they provided that employers could engage outsiders if there were not union members equally qualified, ready and willing to undertake the work. In order to

\footnotetext{
28 Award relating to the Denniston Coal-miners Industrial Union of Workers and the Westport Coal Company, I. Bk. Aw. 175

27 Award covering Canterbury Bootmakers, I. Bk. Aw. 203.

20 Edwards J.

29 Taylor and Oakley v. Mr. Justice Edwards and Others (1900) 18 N.Z.L.R. 876.

so Id. at 886 .

31 Id. at 888

32 I.C. \& A. Act, 1900, consolidating the 1894 Act and amendments; the definition of "industrial matters", s. 2.
} 
avoid arguments over equal qualification and to strengthen their position, unions tried to shut the back door through which non-members may have entered into jobs. The Wellington District Hotel, Club and Restaurant Workers Union in 1915 persuaded the Arbitration Court to insert in the award a clause making union membership a prerequisite to employment. The Court of Appeal upon the question stated for its opinion, whether or not the Court of Arbitration had jurisdiction to insert in an award such a provision, decided in the negative. ${ }^{33}$

The clause in question was considerably different from those found in awards previously made, and to understand the apparent contrary view taken by the Court of Appeal the clause should be quoted at length:

15.(a) If any employer shall hereafter engage any worker who shall not be a member of the union, and who within seven days after his or her engagement shall not become a member of the union, the union may then require the non-unionist worker so engaged to become and remain a member of the union.

(b) If any non-unionist worker employed in any hotel covered by this award refuses to join the union after being requested by the union to do so in accordance with the foregoing clause, then the union may require the employer to dismiss such non-unionist from his service, provided it can replace him or her with a member of the union equally qualified to perform the particular work required to be done.

(c) Any non-unionist refusing to join the union after being requested to do so in accordance with the provisions of this section shall be deemed to have committed a breach of this award, in addition to rendering himself liable to dismissal as aforesaid.

(d) Every non-unionist employed in any establishment covered by this award shall within seven days after the commencement of its operation become and remain a member of the union. Failure to do so shall constitute a breach of the award.

(e) Compliance by any employer with the provisions of this section shall relieve him of all liability under the section.

(f) The provisions of the foregoing clause shall operate only if and so long as the rules of the union permit any person of good character and of sober habits to become a member of the union upon payment of an entrance fee not exceeding 58., upon a written or verbal application, without ballot or other election, and to continue a member upon payment of subsequent contributions not exceeding $6 \mathrm{~d}$ per week.

The secretary of the workers' union shall have the right to interview the workers in any hotel at reasonable times during the week-days.

The learned judges of the Court of Appeal drew a distinction between the preference clause approved in Taylor v. Oakley, ${ }^{34}$ and the above quoted clause, pointing out that the claim in the latter was not to ensure employment for unionists but that: ${ }^{35}$

non-unionists qualified and willing to fill the vacancies . . unless they join an organization of the constitution or management of which they may deeply disapprove, must remain idle, and both they and the employer must suffer, without any corresponding benefit even to the unionists themselves.

Stout C.J. who in the earlier case expressed the view that "the Court [of Arbitration] can fix the status of workmen" 36 objected in strong words against " "conscription' of labour". He stated:

Compulsion is the antithesis to unionism. Unionism imports voluntary action. One might as well speak of "compulsory volunteering" as "compulsory unionism."

\footnotetext{
33 Magner v. Gohns [1916] N.Z.L.R. 529 (C.A.).

34 Supra, n. 29.

3s Supra, n. 33 at 552 per Edwards J.

so Taylor v. Oakley, supra, n. 29 at 886.

${ }^{37}$ Supra, n. 33 at 547.
} 
In his view the Court of Appeal could not read into the Act a right of the Court of Arbitration to compel employers or employees to join unions. ${ }^{38}$

This hard line taken in contrast to the earlier view can be explained by the sharp difference between giving preference to non-unionists and forcing them to join the union. It was emphasized that "power to make the status of a unionist a condition of employment does not include a power... to compel any worker to obtain that status, and to make him punishable for a breach of the award if he fails to do 80. ."39

\section{Compulsion by Statute}

After Magner v. Gohns the essence of the decision of the Court of Appeal was reiterated several times, and all attempts by unions to obtain a more liberal interpretation of the Act to the effect that the Court of Arbitration had power to include in awards a compulsory membership clause were unsuccessful. 40 Preference remained legal, but compulsion to join illegal. Union membership clearly amounted to a distinct advantage but not an absolute prerequisite of obtaining work. The back-door for non-organized labour remained open. In the depressed economy of the early 1930's many unions therefore came to the conclusion that to the growing unemployment and the consequent loss of membership compulsory unionism was the only answer. Membership further shrank as a result of an amendment to the I.C. \& A. Act in 1932 which provided that a dispute could be referred to the Arbitration Court only if both parties agreed to it. Employers frequently refused, therefore many existing awards and agreements lapsed without having been replaced by new ones. Thus preference clauses disappeared, and by the end of 1933 trade union membership was thirty per cent less than had been in $1929 .{ }^{41} \mathrm{As}$ a noted New Zealand industrial relations expert, N.S. Woods, comments "the 1932 legislation engendered great bitterness in the trade unions and a determination that the pendulum which had swung so far against them should be swung equally far in their favour."42

With the coming of the first Labour Government in 1935 these aspirations were realized, and in 1936 the following amendment was passed:43

In every award the Court shall make provision to the effect that, while the award continues in force, it shall not be lawful for any employer bound thereby to employ or to continue to employ in any position or employment subject to the award any adult person who is not for the time being a member of an industrial union of workers bound by that award.

The section made the same provision relating to industrial agreements. ${ }^{44}$

All the objections expressed in Magner v. Gohns were swept aside. Preference was changed to a general compulsion to join a union. The amendment made it unlawful for an employer to employ an adult person who was not, or was not willing to become, a union member. Hare,

ss $I d$.

39 Id. at 553 per Edwards J.

40 Butt v. Frazer [1929] N.Z.L.R. 636.

4 See Woods, Law and Industrial Relations: the Influence of Parliament (1971) 2 Otago Law Review 262 at 270.

42 Id.

43 I.C. \& A. Amendment Act, 1936, s. 18. It was further amended by 8. 37 of the Statutes Amendment Act, 1937, and by 8 . 3 of the I.C. \& A. Amendment Act, 1943; upon re-enactment it became 8. 174(1) of $1 . C$ \& A. Act, 1954 .

"I.C. \& A. Act, id., s. 174(2). The wording is different from that of subsection 1: "there shall be or be deemed to be included a provision ..." etc. 
a critic and observer of industrial relations in New Zealand, commented that compulsory unionism can be: 45

(a) direct, by ordering workers to become union members, and

(b) indirect, by making it unlawful for employers to employ non-unionists.

The effect of the amendment can be described as combining both methods. Legislation preserved the device of the preference clause forming part of the award or industrial agreement, but as its insertion had not been left to the parties' will,46 direct statutory compulsion was achieved notwithstanding that non-compliance could be prosecuted as a breach of award.

\section{"Abolition" of Compulsion}

With the defeat of the Labour Party after fourteen years on the treasury benches and the formation of a farmer-employer backed $\mathrm{Na}$ tional Government ${ }^{47}$ the abolition of compulsory unionism became a live issue. But despite the expression of considerable discontent with it, even on the part of many unionists, the majority of the labour movement, together with a surprisingly great number of employers, wanted to retain it. In 1960 the National Party, which had again been in opposition since 1957, made part of its election manifesto the repeal of section 174 . Having regained power in 1961 the section was repealed and replaced with a number of new sections giving jurisdiction to the Arbitration Court to insert in awards either qualified or an unqualified preference clause. ${ }^{48}$ The amendment provides that, when the parties agree in a settlement or when not less than fifty per cent of the persons bound by the award wish to be union members, "the Court shall insert an unqualified preference provision. ${ }^{49}$ As the Court must include an unqualified clause if the above circumstances are present, very few qualified provisions can be found in awards or industrial agreements. A qualified preference clause will be inserted in all other cases unless the Court sees good reason to the contrary.50 Thus, despite the so-called abolition of compulsory unionism, a preference clause, usually the unqualified one, must be in all awards and industrial agreements. The unqualified preference clause is worded in the following form: ${ }^{51}$

(a) Any adult person engaged or employed in any position or employment subject to this award by any employer bound by this award shall, if he is not a member of a union of workers bound by this award, become a member of such union within 14 days after his engagement, or after this clause comes into force, as the case may require.

(b) Subject to subclause (a) hereof, every adult person so engaged or employed shall remain a member of a union of workers bound by this award so long as he continues in any position or employment subject to this award.

(c) Every worker obliged under subclause (a) hereof to become a member of a union who fails to become a member, as required by that sub-clause, after being requested to do so by an officer or authorized representative of the union, and every worker who fails to remain a member of a union in accordance with sub-clause (b) hereof commits a breach of this award.

is Hare, Industrial Relations in New Zealand, 177, 180-2, 195-9.

"I In 8 . 174(2) the provision of "shall be deemed to be included" makes the actual insertion of the clause irrelevant.

17 In 1949.

48 I.C. \& A. Act, ss. 174-174H as inserted by 8. 2, I.C. \& A. Amendment Act, 1961.

19 Id. $8.174 \mathrm{~B}$.

so Id. s. $174 \mathrm{~F}$.

st It may be of some interest to compare this clause with the one in Magner v. Gohns supra, n. 33. Adult person means a person of 18 years or more. 
(d) Every employer bound by this award commits a breach of this award if he continues to employ any worker to whom sub-clauses (a) and (b) apply after having been notified by any officer or authorized representative of the union that the worker has been requested to become a member of the union and has failed to do so, or that the worker having become a member of the union has failed to remain a member.

A worker is not precluded from obtaining employment by lack of union membership, but he must join within the prescribed period if he wants to retain it. As a rule a request is made, and the fortnight's period then will be counted from the date of the request. Should the union be tardy, a worker might have been in the job for weeks or months before he would be so requested. In fact, as the secretary of the union has a right of entry at all reasonable times upon the premises of the employer to interview any worker, ${ }^{52}$ the request almost always is promptly made.

The qualified preference clause shows great similarity to the ones inserted in the early awards during the first years of the I.C. \& A. Act. The effect is that a non-member may remain such and keep his position if there is no union member equally qualified to perform the work, ready and willing to undertake it. In case of dispute the union has the burden of proving equal qualification. ${ }^{53}$

\section{The Necessity of Membership}

Thus for all practical purposes, union membership has remained a prerequisite for obtaining and retaining work. The question may arise whether it is sufficient to belong to a union, any union, or membership in a particular union would be required. It can be said that prima facie the worker should join the union which is a party to the award or industrial agreement. Indeed, the monopoly position discussed above indicates that no other union can organize in a particular industry. In certain circumstances, however, a worker may be eligible for even two or even more unions: a maintenance engineer in a dairy factory may join the Dairy Workers' Union or may prefer to belong to the Engineers' Union. The Court held that in such a case membership in the Engineers' Union is sufficient compliance with the award..$^{54}$

The obligation to belong to a trade union necessarily should correlate with the right to belong. The amendment purports to take care of this aspect by enacting the following section:

$174 \mathrm{H}$. Every person who by virtue of his employment or intended employment is within the class of which an industrial union of workers is constituted, and who is not of general bad character, shall be entitled to be admitted to membership of the union; and so far as the rules of any union are inconsistent with the provision of this subsection they shall be null and void:

Provided that nothing in this subsection shall apply so as to oblige any union to admit any person to its membership while its maximum membership is fixed by or in accordance with any Act or award or order of the Court if by the admission of that person the prescribed maximum membership of the union would be exceeded.

It is clear that there can only be two exceptions to the general rule that all properly qualified workers must be admitted to membership:

(1) General bad character of the applicant.

(2) Maximum membership of the union.

52 In every award and industrial agreement there is a clause giving right of entry.

s2 See Auckland Plumbers I.U.W. v. Hamilton Hardware Co. Ltd. [1928] G.L.R. 509.

so N.Z. Dairy Factories and Related Trades Employers' Industrial Union of Workers v. V. J. Cooper. Opinion of the Court of Arbitration on case stated by a Magistrate, (1955) 55 Bk. Aw. 1212. 
Who is "of general bad character"? From parliamentary debates ${ }^{55}$ it would appear that this expression covers mostly persons convicted for thefts and habitual drunkards who would be a danger for their fellowworkers' personal property, and who, especially when working with machinery, could cause injuries to them. Thus, apart from a few clearcut cases, the allegation of general bad character can put the union in a difficult position, as a refused applicant may commence mandamus proceedings, or claim damages if he can prove that but for the lack of union membership he would have had work. ${ }^{56}$ The right of admittance into the union, however, does not confer an indefensible right to remain a member so long as the person admitted remains "not of general bad character." 57 Therefore, the duty to admit under s. $174 \mathrm{H}$ is not inconsistent with the union's right to suspend or expel a member for reasons provided in the rules.

The restriction based on maximum membership seems to be incongruous with compulsory unionism; it is certainly effective in preserving a trade union, or rather a special craft represented by the union, as a monopoly for a limited number of persons. The numerius clausus, however, never can be imposed by the union itself; it must be fixed by statute or by the Arbitration Court. In fact the effect of the proviso on union membership is negligible.

\section{Conscientious Objection}

Exemption from union membership may be obtained on grounds of conscientious belief by persons who can show that their sincerely and honestly held religious or other views are in serious conflict with the idea and fact of belonging to a trade union. Under the original legislation $^{58}$ the definition of "conscientious belief" was restricted to religious character, but it has been enlarged to include any kind of genuine and earnest objection whether or not connected with a faith or organized sect. 59

The Registrar of Industrial Unions refers the applications for exemption filed with him to the Conscientious Objection Committee consisting of three persons appointed by the Minister of Labour. ${ }^{60} \mathrm{~A}$ time and place will be fixed for a hearing and, beside the applicant, the secretary of the union involved, the secretary of the national organization of workers that is most representative of workers in New Zealand, and a representative of the Crown may appear. If the application involves other unions beside the one which opposes the application they can also be invited.61 After hearing the applicant, the representatives of the Union, the Federation of Labour, other unions and the Crown, the Committee, if it is satisfied that the objections are genuine, will grant exemption. ${ }^{62}$ The Registrar upon being notified of such a decision will issue a Certificate of Exemption from membership in the union for a

\footnotetext{
ss [1961] N.Z. Parl. Deb. 2286.

so See Gillard v. McFarlane [1930] N.Z.L.R. 258; Hardgreaves v. Wellington Waterside Workers I.U.W. [1932] N.Z.L.R. 1211; Miller v. Wellington Seamen's Union [1932] G.L.R. 355; Australian Iron and Steel Ltd. v. Australasian Coal and Shale Employees' Federation (1957) I.F.L.R. 54.

57 See Armstrong v. Kane [1964] N.Z.L.R. 369.

s8 1.C. \& A. Amendment Act 1951, s. 6.

59 I.C. \& A. Act, s. 175(1) as inserted by I.C. \& A. Amendment Act, 1967, s. 8

60 Id. 8. 175(2) and 175A.

61 Id. s. 175(3), (4) and (5). The most representative national organization of workers is the Federation of Labour (F.O.L.), and when required its representative appears.

62 Id. 8. 175(8).
} 
period specified. In order to receive the certificate the applicant must pay to the credit of the Consolidated Revenue Account an amount equal to the subscription fixed by the union. ${ }^{63}$ This provision is quite clearly for the purpose of excluding even the possibility of frivolous applications. At the same time the union secretary will also be notified of the exemption. The Certificate may be renewed without reference to the Committee. ${ }^{64}$ Pending the Committee's determination the applicant may stay out of the union, but if the decision is against him he must join immediately, and pay all fees and subscriptions for the period between the application and the decision. ${ }^{65}$ The Committee may admit and accept any evidence whether or not it would be admissible in a court of law. Further, the Committee may sit at such times and places as may be determined by the chairman.66 An exempted person may obtain and retain any employment without either he or the employer committing a breach of the preference clause. ${ }^{67}$ An employer, however, cannot rely on conscientious objection, however sincere his beliefs may be, and apply for exemption from employing unionists, such being held by the Court of Arbitration in Taranaki and Wellington Butchers. ${ }^{68}$ If the Registrar is of the opinion that any determination may have been procured by fraud or was made in error or that new and material evidence is available, he may apply to the Committee to have the application reheard. ${ }^{69}$

What happens if an exempted person subsequently changes his occupation such that he would be required to belong to a different union? Does the Certificate of Exemption cover such a contingency? It does only in cases when that different union was represented at the original hearing; otherwise that union may apply to the Registrar for a rehearing of the application on the ground that new and material evidence is available. The Registrar then refers the matter to the Committee, which may in its discretion rehear the application, and cancel, vary or confirm its previous determination. ${ }^{70}$

\section{Enforcement of Union Preference: Court Action and Direct Action}

Reference has already been made to the fact that non-compliance with the preference clause is a breach of award, and both the employer and employee can be prosecuted. It is a prerequisite of commencing prosecution that the worker must have been requested by an officer or authorized representative of the union to become a member. The union after the expiry of the required period of fourteen days may start prosecution. The statute places no duty either on the Department of Labour or on the Inspector of Awards or other officer of the Public Service to enforce or in any way police the observance of preference clauses. ${ }^{71}$

The method of enforcement is an action for breach of award or industrial agreement commenced in a Magistrate's Court. ${ }^{72}$ The penalty

\footnotetext{
6. Id. 8. 175(10).

of Id. 175(11).

as Id. s. $175(7)$.

os Id. 8. 175 B.

${ }^{67}$ Id. 8. 175(14).

os (1962) 62 Bk. Aw. 366.

69 I.C. \& A. Act, s. $175 \mathrm{C}(8)$

${ }^{30}$ Id. 8. $175 \mathrm{C}(9)$ and (10).

"Id. B. 174 G.

72 Id. 8 200(1).
} 
imposed on the employer can be two hundred dollars-in respect of every breach, and on the worker twenty dollars. ${ }^{73}$ The penalties recovered will not be paid to the union bringing the action but to the public account. ${ }^{74}$ The Magistrate may state a case for the opinion of the Court of Arbitration. ${ }^{75}$ Against the Magistrate's judgment any party may appeal to the Arbitration Court: ${ }^{76}$

(a) On any matter of fact in any case where the amount exceeds ten dollars, and

(b) On a point of law, with the leave of the Magistrate in any case where the amount does not exceed ten dollars, and without such leave in any other case.

Direct industrial action against an employer for non-observance of the union membership as a prerequisite of employment cannot be legally maintained. This is a direct consequence of registration whereby the union impliedly promises that it will remain within the four corners of the I.C. \& A. Act and never resort to strike. ${ }^{77}$ Thus, strictly speaking a Quinn v. Leathem ${ }^{78}$ situation, where a boycott was organized in support of a demand to dismiss a non-union worker, or a Rookes v. Barnard ${ }^{79}$ imbroglio where the B.O.A.C. faced a threat of concentrated withdrawal of work by all its draughtsmen unless the employment of Rookes was terminated, cannot arise. There has recently been, however, one case where unions applied, or were forced to apply, a more direct approach: Pete's Touring Services Ltd. v. Northern Drivers Union. ${ }^{80}$

Pete's Touring Services Ltd. operated a large steel barge to carry cargo in bulk, and used a mobile crane together with forklifts for loading and unloading. Sand was unloaded from the barge with the help of this mechanical equipment directly on to trucks driven to the right positon on the wharf. By this method the company did not need to employ waterside labour. As a result, even with the hire of forklifts, its operating costs were minimal, and it could offer its services on much lower rates than any other similar business. The Waterside Workers Union soon became aware of the position, and advised the managing director of the company that the Waterfront Industries Act, 1953 and the current award ${ }^{81}$ gave preference to watersiders for such work. The company refused to consider the union's rights, and the complaint was referred to the Port Conciliation Committee. Upon the managing director's refusal to appear before the committee, the matter was sent to the Waterfront Industry Tribunal. In order to counteract the passive noncooperation of the managing director, the union approached the Drivers' Union in turn, through its organizer informed the drivers' employees, the Ready Mixed Concrete Limited, of the state of affairs, and indicated that as the company's barge had already been declared black, disruption in the work would very likely follow. The manager of Ready Mixed Concrete Limited formed the opinion that it would not be prudent to accept any more sand delivery until such time as the situation was clarified.

\footnotetext{
73. Id. 199.

74 Id. 8. 202(1).

75 Id. s. 203.

36 Id. 8.204.

77 Id. s. $189-195$ make all strikes-and lockouts-unlawful.

78 [1901] A.C. 495.

:9 [1964] A.C. 1129 .

Bo [1970] N.Z.L.R. 32
}

o1 S. 29. The award for waterside work is called a principal order and is made by the Waterfront Industry Tribunal; in the present case the relevant clause is clause 27 of General Principal Order No. 279. 
The consequence was that the business of the company came to an abrupt halt. The company sued the union for damages totalling fortyone thousand, seven hundred and thirty-nine dollars alleging inducement of breach of contract, intimidation and conspiracy. The Court held that the claim failed under all three heads. Speight J. found that:

(1) Intimidation, defined as "procuring economic harm to another by the use of unlawful threats to curtail that other's freedom of action" was not proved; it had not been shown that the defendant was acting illegally or employing illegal means;

(2) Inducement of breach of contract was proved but the defendant had a duty to interfere, and was justified in doing so;

(3) Conspiracy could not be upheld as the narrower defence of justification already established with regard to inducement of breach of contract $a$ fortiori is applied to the allegation of conspiracy.

Thus, the direct action taken by the union against the company was held justified in the circumstances. While the decision as a whole can be accepted as correct and just, and there is no doubt that the union was forced to take this step by the refusal of the company to appear before the Port Conciliation Committee, certain statements of the learned Judge may raise difficult problems. In arriving at his decision that there was no intimidation, His Honour stated: ${ }^{82}$

... was it an illegal act on [the part of the local organizer of the Drivers' Union] to discuss [the possibilities of disastrous economic consequences] with the indication that his Union, in a way which was not defined, would join in bringing . . . pressure upon Ready Mixed? As I understand it, with particular reference to Part $\mathbf{X}$ of the Industrial Conciliation and Arbitration Act 1954, a strike as such is not illegal and indeed, there are lawful methods of striking. A fortiori it may be lawful to threaten a strike, depending on the type of action contemplated.

Speight J. apparently was influenced by English common law which views strike action as prima facie lawful..$^{83}$ In New Zealand, contrariwise, the I.C. \& A. Act makes all strikes unlawful and subject to penalties, notwithstanding that a secret ballot taken among the workers favoured it. ${ }^{84}$ The only visible effect of a positive ballot is the application of somewhat lesser penalties. ${ }^{85}$ Lawful strike is possible only for unregistered unions, subject to certain prerequisites; ${ }^{86}$ thus the union should deregister itself before legally resorting to direct industrial action.

Further aspects of the case and discussion of the right to strike are irrelevant to the main theme of this essay. Although the decision must rest on its own facts, and cannot be regarded as establishing a right to apply any kind of direct economic pressure, even less to threaten strike; its significance lies in demonstrating that, where the statutory means of enforcing preference of unionists for certain reasons are not effective, self-help may be allowable.

\section{Evaluation of Compulsory Unionism}

The so-called abolition of compulsion did not essentially change the position of workers seeking employment, and it is obvious that, by virtue of the unqualified preference clauses in nearly all awards and industrial

12 Supra, n. 80 at 44.

23 See Morgan v. Fry [1968] 2 Q.B. 710.

A S. 191 requires that a secret ballot be taken if there is a proposal that there shall be a strike; s. 191(8) expressly provides that nothing in the section shall be deemed to render lawful any strike or lockout which would otherwise be unlawful.

ss Fines without ballot: two hundred dollars, with one hundred dollars for workers; one thousand dollars and five hundred dollars-for union officials; see s8. 192, 193 and 195.

so Labour Disputes Investigation Act, 1913, 8s. 7-10. 
agreements, compulsory unionism has de facto remained in force. From the point of view of a jobseeker there is no difference between compulsion by statute and by award or industrial agreement. It can be argued that the right to associate, as an important aspect of individual liberty, should have as its necessary counter-freedom the right to keep away from any kind of association; 87 compulsion turns a voluntary action, a freedom, into conscription or oppression. ${ }^{88}$

Against this the counter argument may be presented that trade unions are not to be equated with clubs or other purely voluntary organizations: they have become "parts" of the social machinery of the [modern] state, "b9 "burdened with certain legal obligations corresponding to [their] social function." 90 Their activities in obtaining better wages and working conditions benefit all workers, and to accept the advantages and rights achieved by their struggle without being a member and contributing to the funds is unfair; thus "freedom not to join a union is ... freedom from paying union subscriptions ... to take a free ride on the backs of one's fellow workers." 91

In New Zealand itself the concept and practice of compulsory unionism was severely criticised, and grave doubts were expressed whether it in fact strengthened unionism. A.E.C. Hare, while recognising that it has financially strengthened unions and extended protection to groups of workers who needed it, states that: 92

\begin{abstract}
... it has done nothing to remedy the great weakness of the unions, their lack of democracy. It has done nothing to raise the general level of interest in unionism amongst the members, nor has it encouraged them to play a greater part in their organisation, nor to accept responsibility, nor to work for the union. In fact, compulsory unionism has not made unionists.
\end{abstract}

Woods, another noted New Zealand expert, did not mince his words: ${ }^{93}$

\begin{abstract}
Compulsory unionism weakened the trade unions. With union dues flowing in automatically there was no necessity on trade union officials to do anything to maintain and expand membership. Their task was not to sell trade unionism to workers, not to hold on to members, not even to justify taking their contributions, for the law looked after all these things. Many trade union managements succumbed to this opiate. And, since the members similarly could do little about their membership and their contributions, it is not surprising that apathy to union matters was so often their main characteristic.
\end{abstract}

Every now and then there are movements among trade unionists to call for a real abolition of compulsory unionism which, as one union member said, "had been a thorn in everybody's side for a long time."94 Despite such moves, however, the majority of members does not show any inclination to have the law changed-whether out of loyalty or apathy it is a different question. The employers, likewise, by the fact that their representatives always agree to unqualified preference clauses, have indicated their readiness to accept one hundred percent unionism

S7 See Szakats, Trade Unions and the Law 168.

a Cf. Stout C.J. in Magner v. Gohns, supra, n. 33 at 547.

" Hutt, British Trade Unionism 5.

$\infty$ Grodin, Union Government and the Law 90.

91 Grunfeld, Trade Unions and the Individual in English Law 50.

92 Hare, supra, n. 45 at 197.

Q3 Woods, Needed Reforms in Industrial Conciliation and Arbitration, Ind. Rel. Centre, Victoria Univ. of Welling ton, 1970, 5. Mr. Woods is a former Secretary of Labour, at present a member of the Industrial Relations Centre, V.U.W., Wellington.

Evening Post, Wellington, N.Z., March 14, 1971. 
in their workforce or at least their reluctance to make this question into a contentious issue, and for the sake of a few stray workers jeopardise industrial peace. ${ }^{95}$ Thus, it is not likely that any government would be prepared to disturb the present state of affairs which has become part and parcel of the New Zealand industrial scene.

\section{GREAT BRITAIN}

\section{The Principle of Voluntariness}

Trade unions in the United Kingdom were recognised as lawful associations by the Trade Union Act 1871 . Since then the basic idea has always been that trade unions are voluntary associations, the principle of voluntariness being manifested in two respects:

1. Workers have a right, but not a duty, to join a trade union.

2. Unions are under no duty to admit every applicant, and have the right to refuse membership.

Examining these two points in reverse order it is a logical consequence that unions are entirely at liberty to impose any conditions on admittance they think fit, and may refuse applicants whom they do not consider eligible. The rules, therefore, can contain any kind of qualifications and restrictions on membership except compulsory contribution to a political fund which is expressly prohibited by statute. ${ }^{96}$ While the prerequisite to belong or not to belong to any political party could lawfully be made part of the eligibility rules, unions "have not taken advantage of this loophole because they do not believe in organising on the basis of politics of their members."97 Unions, in general, do not discriminate on racial, religious or national grounds though until the Race Relations Act, $1968^{98}$ there had been no law to prevent them from doing so. This Act makes it unlawful on grounds of colour, race or ethnic or national origins to refuse a person admittance in a trade union on the same terms as other persons. ${ }^{99}$ Eligibility rules are based on the criteria of occupation, occupational skill, good character and good health. ${ }^{100}$

As the purpose of this article is not the examination of the union's right to accept or reject applicants for entry but the evaluation of the workers' position with regard to the necessity of membership as an indispensable prerequisite for obtaining and retaining work, the relevant issues will be discussed from the individual workers' point of view. Although, as has already been said, the worker's freedom whether to join or not to join has always been recognised, in practice certain arrangements can inhibit his choice of a specified trade union, and closed shop agreements may even lawfully counteract his right of not joining thereby introducing a de facto compulsory unionism. These inhibiting, or even prohibiting, factors arise (a) from the Bridlington agreement, ${ }^{101}$ whereby unions belonging to the Trade Union Congress regulate their

os Szakats, supra, n. 87 at 168.

* Trade Union Act (Imp.) 2\&3 Geo. S.C. 30, 8. 3(1)(b).

97 Roberts, Trade Union Government and Administration in Great Britain 38.

os Race Relations Act, 1968, c. 71.

99 Id. 8. 4. This section equally applies to organization of employers or other organizations concerned with the carrying on of trades, businesses, professions and occupations; yet the Jewish Bakers' Union naturally admits only persons who answer to both descriptions, however this is not a social but a religious ground.

100 For a valuable analysis on admission see Grunfeld, Modern Trade Union Law 16 et seq.; and Rideout, supra, n. 3 at 40 .

101 Made by unions affiliated to the Trade Union Congress in 1939 at Bridlington; it provides for a T.U.C. Disputes Committee for adjudicating complaints on "poaching"; the awards have no legally binding force. 
competition for members, (b) from the existence of small, breakaway unions which are not recognised for collective bargaining purposes, but mainly (c) from union security agreements, or commonly called, the closed shop. ${ }^{102}$

\section{Closed Shop Patterns}

The expression "closed shop" covers a number of different, though related, arrangements. The essence of all such arrangements briefly is that only union members can be employed. By this device the union holds effective control not only over entry into its ranks but over all the available jobs; obtaining employment and union membership go together and cannot be separated.

Accepted patterns of closed shop arrangements existing before the coming into operation of the Industrial Relations Act, 1971 have been classified by a leading expert on this subject in the following way:

1. Pre-entry closed shop: The worker must already be a member of the union before he can enter into an employment contract, and correspondingly before an employer can offer his a job. Entry into employment-and simultaneously into union membership ${ }^{104}$-can be controlled by four methods which ensure a varying degree of control.

These are:

(a) Labour supply closed shop: the union itself functions as a labour placement centre, and it has the exclusive right of supplying workers to the employers. As a consequence the employers' right to select a person is diminished to the point where they simply have to accept the man sent-subject to a right to object on certain limited grounds. ${ }^{105}$

(b) Labour pool shop: a recognised pool of labour is created by agreements between employers and the unions. The employer has a wider right to select than under method (a), and can employ any person from the pool without notifying the union. The union controls entry into the pool by the fact that its members may only be admitted. When the demand for labour is high, and the pool has been exhausted, then outside labour may be recruited. ${ }^{106}$

(c) Craft qualification shop: admission to the union is restricted to persons holding certain prescribed craft qualifications who necessarily have a monopoly on jobs requiring their skill. The union in such cases normally has succeeded in agreeing with the employers that the proportion of apprentices should be a certain fixed proportion of the fully trained craftsmen, and further that the union may take part in the selection of trainees. ${ }^{107}$

(d) Promotion veto shop: if the senior employee due for promotion to a higher position is not a union member, he must be by-passed in favour of the next senior union member. ${ }^{108}$

2. Post-entry closed shop: this is a method similar to the requirements of the preference clauses in New Zealand. The employer is completely free to engage any person, but the new employee must, either immediately or within a given short period, join the union subject to the penalty of dismissal which the union can enforce by industrial action against the employer.

Other important considerations relate to the scope of the closed shop agreement: whether it is plant wide, industry wide or nation wide, and whether it requires membership of a specified union, or of any of two or more named unions, or merely of any trade union.

\footnotetext{
102 See Grunfeld, supra, n. 100 at 28 et seq.

103 McCarthy, The Closed Shop in Britain 16 et seq.

10. Id. at 17: Entry to the job is made contingent on entry to the union. By controlling, or restricting, entry to the union, entry to the job is regulated; this practice may be called job entry control.

105 This is the method in the newsprint worker supply, id. at 17 and 38 .

106 E.g., dock workers employed by the National Dock Labour Board. Several unions are involved: the Transport and General Workers' Union, the Stevedores' and Dockers' Union, the Watermen's Union and the General and Municipal Workers' Union to mention only the main ones. Id. at 17 and 42.

${ }_{107}$ E.g., printers bookbinders, paper workers. Id. at 45.

${ }_{108}$ E.g., Iron and Steel Workers. Id. at 20 and 49.
} 
With the enactment of the Industrial Relations Act, $1971^{109}$ the wellestablished pattern of closed shop arrangements is bound to be reshaped, and a new network of closed shop and agency shop agreements will emerge. For this reason attention should be focussed on the relevant parts of the statute.

\section{Rights of Workers under the Industrial Relations Act}

Part II of the Act, entitled "Rights of Workers", 110 while reaffirming the unions' freedom to organise, emphasises with equal strength the principle of voluntariness; it leaves the choice to belong, or not to belong to a trade union entirely to the individual workers, and at the same time it declares all existing closed shop arrangements unenforceable.

The Act lays down in unequivocal language that every worker has the right:
(a) to be a member of such trade union as he may choose; ${ }^{111}$
(b) to take part, if he is a member, in the activities of the trade union;
(c) to seek or accept appointment or election for office of the trade union;
(d) to hold such office, if so elected or appointed; ${ }^{112}$
(e) to refuse, if he so desires, to be a member of a trade union or other organisation of workers, and
(f) to refuse to be a member of a particular trade union or other organisation of workers. ${ }^{113}$

This right of refusal, however, is qualified by the possibility of agency shop agreements and approved closed shop agreements. ${ }^{114}$

It is not without significance that the statute distinguishes between trade unions and other organisations of workers with regard to the freedom of abstention. The reason appears to be that the expression "trade union" has been reserved by the statute for unions registered under it. 115 As registration is voluntary, unions may wish to continue functioning as unregistered organisations. The use of language, presumably purposefully chosen, clearly indicates that workers have a right to belong only to registered trade unions, but they may refuse to join either any registered trade union or an unregistered workers' organisation. This, however, does not mean that they are prohibited from being members of an unregistered union; the significance of the distinction merely ensures that preventing a worker from joining such an unregistered organisation will not constitute an unfair industrial practice.

The employer commits an act of unfair industrial practice if he:116

(1) prevents or deters a worker from exercising his rights conferred on him (as set out above);

(2) dismisses, penalises or otherwise discriminates against a worker by reason of his exercising any such right, or

100 Supra, n. 4, provisions of the Act have come into operation at different times: the Registry was set up in October, 1971; the Commission on Industrial Relations in November; the Industrial Relations Court and the Industrial Arbitration Board in December; other provisions commenced in 1972.

110 I.R. Act, 8s. 5-33.

III Id. 8. $5(1)(\mathrm{a})$.

112 Id. 8. $5(1)(c)$.

113 Id. 8. $5(1)(\mathbf{b})$.

I14 Id. 88. 6-21, to be discussed, infra.

IIs Id. 8. 167(1) which refers to 8. 61 (3) which provides that:

in this Act 'trade union' means an organization of workers which is for the time being registered as a trade union under this Act.

116 Id. 8. 5(2). 
(3) refuses to engage a worker on the grounds that at the time of applying for engagement:

(a) he was a member of a trade union or of a particular trade union, or

(b) he was not then a member of a trade union or other registration of workers, or of a particular trade union or other organisation of workers or of any of two or more particular trade unions or other such organisations.

The distinction between registered and unregistered unions should again be carefully noted for refusing to employ worker because he belongs to an unregistered organisation will not amount to an unfair industrial practice. Furthermore, the statute expressly provides that the employer shall not be regarded as preventing or deterring a worker from exercising his rights by encouraging the worker to join a specified trade union which has recognised negotiating rights. ${ }^{117} \mathrm{If}$, however, the employer confers any benefit on workers who refrain from exercising their rights of joining or not joining a union, and at the same time withholds such benefit from those who refuse to do so, he will be regarded as discriminating against the second category of employees. ${ }^{118}$

Likewise, it is an unfair industrial practice:

(a) to call, organise, procure or finance a strike or to threaten to do so, or

(b) to organise procure or finance any irregular industrial action short of strike, or to threaten to do so

for the purpose of exerting pressure on an employer and inducing him to discriminate against a worker on the ground that: ${ }^{119}$

(a) he is a member of a registered trade union, or

(b) he is not a member of a registered trade union or of an unregistered organisation.

The expression "irregular industrial action short of strike" is defined as any concerted course of conduct, other than a strike, carried on by a group of workers with the intention of preventing, reducing, or otherwise interfering with, the production of goods or the provision of services in breach of their contracts of employment. ${ }^{120}$ The offence can be committed by any registered trade union, unregistered organisation, their officials or any other person. ${ }^{121}$

\section{Approved Closed Shop Agreements}

In line with the assurance of workers' rights in respect of trade union membership the statute explicitly declares void all existing closed shop agreements, whether of pre-entry or post-entry effect.122 A post-entry agreement, however, may be approved by the National Industrial Court upon joint application by the employer of employers' association ${ }^{123}$ and the registered trade union. Before the Court can make an order approving the proposed draft agreement it must be referred for examination and report to the Commission on Industrial Relations as to whether or not such agreement is necessary in order: ${ }^{124}$

(a) to enable effective union organisation,

(b) to maintain reasonable terms and conditions of employment, and continuity of employment,

${ }^{117}$ Id. 8. 5(3).

138 Id. s. 5(4).

119 Id. s. 33(2) and (3).

120 Id. s. 33(4).

121 Id. 8. 33(3).

122 Id. s. 7.

123 Id. 8. 17; Sched. 1, para 1.

124 Id. Sched. 1, para. 5(1). 
(c) to promote and maintain stable arrangements for collective bargaining,

(d) to prevent collective agreements from being frustrated or dishonoured.

The Commission must also be satisfied that in the circumstances the above purposes can be achieved only under a closed shop agreement, and that an agency shop agreement is not suitable. ${ }^{125}$ If after due examination the Commission comes to the conclusion that a closed shop agreement is justified it prepares a report to the Industrial Court recommending approval. Copies of the report will be sent to the applicants and the Secretary of State; further, it will be published in an appropriate manner. ${ }^{126}$ The Court then allows a period of not less than one month nor more than three months for the purpose of enabling the conducting of a ballot among the workers concerned as to whether or not the agreement is supported by them. ${ }^{127}$

At this point a further application to conduct such a ballot may be made by at least one-fifth of the relvant workers. ${ }^{128}$ In the absence of an effective application within the prescribed period the Court makes an order approving the proposals embodied in the draft agreement. ${ }^{129}$ Similarly an order shall be granted if the ballot indicates that the majority of workers eligible to vote on the ballot, or at least twothirds of those who actually voted, favoured the proposed agreement. ${ }^{130}$ If the result of the ballot does not show the majority required, the Court must refuse approval, and no further application may be filed for at least two years. 131

It is to be emphasised that a closed shop agreement will be approved only in exceptional circumstances "where the character of employment is such that good industrial relations can only be safeguarded and maintained if workers are required to belong to a registered trade union, and may not exercise an option to be contributing nonmembers." 132

Where the court has approved a closed shop agreement the employer to whom it applies may dismiss, penalise or otherwise discriminate against, or refuse to engage a worker who is not or is unwilling to become a member of the registered union bound by the agreement. ${ }^{133}$ Workers already in employment are normally given three months to join the union, while for workers engaged subsequently the period is one month. The Secretary of State may shorten both these periods. ${ }^{134}$

Special exemption may be granted to conscientious objectors. Any workers objecting on grounds of conscience to becoming a member can propose that in lieu of union fees he will pay an appropriate contribution to an agreed charity. If the trade union agrees to the proposal, to the charity, and to the amount to be paid, the worker will be "specially exempted". ${ }^{135}$ In case of dispute as to:

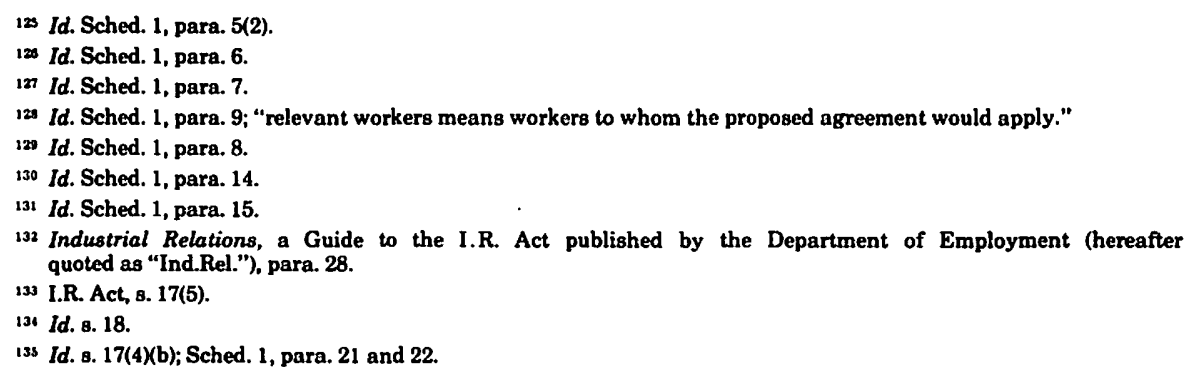


(a) whether the objections are on genuine conscientious grounds; or

(b) which charity should receive the contributions; or

(c) what amount of contributions would be appropriate; or

(d) whether the agreement provides for such contributions either by periodical payments only, or by periodical payments and an initial payment,

the matter will be referred to an industrial tribunal. ${ }^{136}$

\section{Agency Shop Agreements}

An agency shop agreement differs from a closed shop agreement in the respect that under an agency shop agreement a worker has the right to keep away from the union, if he is prepared to pay the appropriate contributions to it. The workers must either belong to the union, orwithout membership rights and also without all other obligations-must pay the appropriate membership fees. ${ }^{137}$ A contributing non-member pays a maximum amount related to the initial payment and to the regular periodical subscriptions by members. ${ }^{138}$ Accordingly the criterion upon which an employer may dismiss, discriminate against, or refuse to engage a worker is not membership, but contribution to the union funds. ${ }^{139}$

Some workers may, however, object to paying contributions to an organisation of which they, by the very fact of refusing to be members, manifestly disapprove. By a procedure similar to that under closed shop agreements the worker may on the ground of conscientious objection, offer to pay an equivalent contribution to a charity as agreed between him and the union. ${ }^{140}$ If there is disagreement as to:

(a) whether his conscientious objection is genuine, or

(b) which charity should receive the contributions, or

(c) what amount of contribution to charity would be equivalent to contributions to the trade union,

the dispute will be decided by an industrial tribunal. ${ }^{141}$

The normal way to establish an agency shop agreement is by voluntary negotiations between the union and the employer, or employers, or a registered employers' association. ${ }^{142}$ Where the employer is unwilling to enter into such an agreement the trade union or unions may apply to the Industrial Court to arrange the taking of a ballot on the issue. ${ }^{143}$ It is to be noted that an application to introduce an agency shop agreement can only be made in respect of the workers of a single employer. The Court cannot order a ballot of employees of two or more different employers. If the agency shop would cover several employers then, lacking voluntary agreement, separate ballot applications must be made with regard to every employer. ${ }^{144}$

Before acting on the application the Court must be satisfied that; ${ }^{145}$

(a) there has been no previous agency shop ballot within two years, and

(b) the trade union is a registered one recognised by the employer as bargaining agent for the workers concerned.

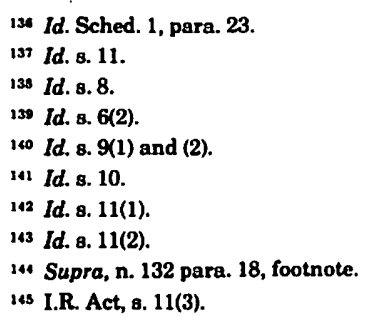


If satisfied, the Court will request the Commission on Industrial Relations to take a ballot whether or not the workers wish to establish an agency shop agreement. The Commission has the power to decide whether the ballot should extend to all workers falling within the range specified in the application or whether it should be limited to part of them.146 The purpose of this discretion is to ensure that the agency shop and bargaining rights extend to the same bargaining units so far as possible. ${ }^{147}$

Further, the Commission must make sure that there is no dispute in respect of the bargaining rights of the union which would render the proposed agreement ineffective. If it comes to a negative conclusion, there will be no further action until the problem is resolved either by voluntary agreement between the parties, or by an application to the Industrial Court to settle the dispute and declare the sole bargaining agent. When the problem has been satisfactorily settled, the application for agency shop ballot can be re-submitted. ${ }^{448}$

After the conclusion of the ballot, if the majority of the workers eligible to vote, or at least two thirds of those actually voting, favoured the introduction of an agency shop, the employer will be under a statutory duty to enter into such an agreement and to carry it out so long as it remains in force. If the result of the ballot is negative then the establishment of an agency shop agreement will be barred for two years, and during that time any inducement of workers by the employer to join a union, whether registered or unregistered, and any attempt to introduce an agency shop agreement will amount to unfair industrial practice. ${ }^{149}$

\section{Discontinuance of Agreements}

Both an agency shop and an approved closed shop agreement may be terminated after two years by a subsequent ballot if at least one-fifth of the workers covered by the agreement apply to the Industrial Court. The applicable procedure is essentially the same as in the case of the ballot for the introduction of agency shop or closed shop. If the majority of workers eligible to vote, or two thirds of those actually voting, are not in support of the continuation of the agreement in question, the Court will rescind the agreement, and for a period of two years prohibit any attempt to introduce a new one. 150

Should the Industrial Court find that a report made by the Commission as to the result of a ballot was incorrect, and that it would be just and equitable in the circumstances to rectify the error without a further ballot, it may make an order amending the result. Alternatively, the Court may quash the ballot if it was wrongly conducted and order a fresh one to be held.151

It is of interest to observe that as a consequence of the declared rights in respect of trade union membership, modified by agency shop and approved closed shop agreements, workers can establish four different kinds of relationship with the trade union. They can be:

\footnotetext{
146 Id. 8. 12(1) and (2).

147 Supra, n. 132, para. 19.

148 I.R. Act, s8. 12(1) and 45.

149 Id. B. 13.

130 Id. 63. 14 and 15(3); sched. 1, para. 16-20.

181 Id. 8. 160
} 
(a) Members, paying full union dues and having full membership rights;

(b) Contributing non-members, paying contributions to the union equivalent to union dues but having no other duties and, naturally, no membership rights;

(c) Conscientious objectors, paying contributions to an agreed charity equivalent to union dues; and

(d) Non-members.

Category (b) is possible only under an agency shop agreement, category (c) both under an agency shop and closed shop agreement. Category (d) is lawful where there exists neither of such agreements, but not otherwise.

\section{Enforcement}

The rights of workers granted by section 5 can be enforced by presenting a complaint to an industrial tribunal of an unfair industrial practice. If the complaint is against an employer and the tribunal finds it well founded, the tribunal may grant either or both of the following remedies: 152

(a) An order determining the rights of the complainant and the employer in relation to the action specified in the complaint;

(b) An award of compensation to be paid by the employer.

Actions on tort in the High Court or the county courts cannot be brought on the ground of wrongful acts which amount to unfair industrial practices. 153

Can a trade union, which has been successful in establishing an agency shop agreement or an approved closed shop agreement thereby bringing about one hundred percent union membership, ${ }^{154}$ enforce the dismissal of a recalcitrant worker by direct action against the employer in the old style of Quinn v. Leathem, ${ }^{155}$ or as it happened more recently in Rookes v. Barnard. ${ }^{156}$ The answer is No. The Act clearly makes it an unfair industrial practice to organise, or threaten to organise a strike or other irregular action short of strike, for the purpose of exerting pressure on the employer. ${ }^{157}$

\section{UNITED STATES}

\section{From "Yellow Dog" Contracts to Closed Shop}

The "yellow dog" contracts whereby employers could prohibit their workers from joining a trade union were declared to be unenforceable and contrary to public policy by the Norris La Guardia Act ${ }^{158}$ in 1932, and three years later the Wagner Act ${ }^{159}$ guaranteed employees the right to "self-organisation, to form, join or assist labour organisations" and also "the right to refrain from any or all of such activities except to the extent that such right may be affected by an agreement requiring membership in a labour organisation as a condition of employment as authorised in section 8(a)(3)."160 The Act made it an unfair labour practice for an employer (inter alia): ${ }^{161}$

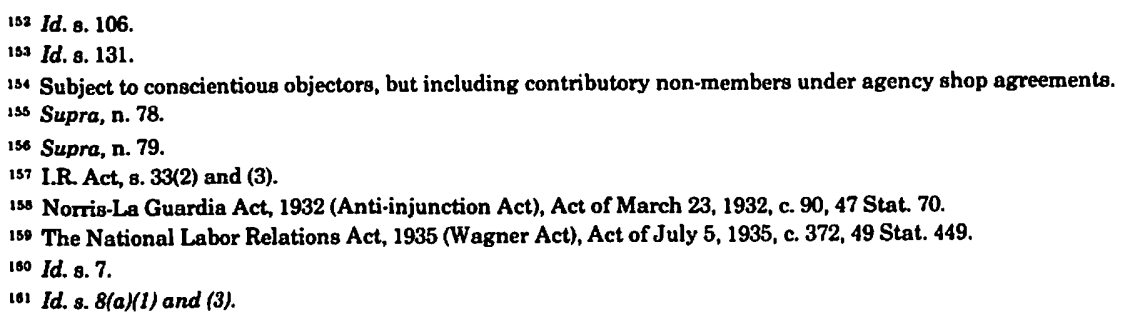


(1) to interfere with, restrain or coerce employees in the exercise of the rights guaranteed in section 7 ; and

(3) by discrimination in regard to hire or tenure of employment or any term or condition of employment to encourage or discourage membership in any labour organisation.

Employees, thus, were given complete freedom to join or to refuse to join a union, and membership or lack of it could have no relevance in an employment contract. The statute, however, allowed certain forms of agreements whereby all job applicants had to be members of a certain union, or if not, had to join within a stated period. The proviso to paragraph (3) was worked as follows: ${ }^{162}$

Provided that nothing in this Act or in any other statute of the United States, shall preclude an employer from making an agreement with a labor organisation .... to require as a condition of employment membership therein ...

Forms of union security agreements which were utilized by trade unions in the United States can be divided into the following categories:

1. Closed shop: only persons who are already members of the union which is a party to the agreement may be employed.

2. Union shop: any person may be employed but upon employment he must join the union within a certain period, otherwise he must be dismissed.

3. Preferential hiring: union members have preference to all vacancies but if no member is available any person may be engaged; such person is under no obligation to join the union.

4. Maintenance membership: any person can be employed whether union member or not; members, however, cannot resign from the union while in employment.

5. Agency shop or contributory non-membership: non-members must pay a certain monthly or weekly contribution to the union for the support of the bargaining unit. ${ }^{163}$

6. Open shop: this is simply a lack of any kind of security agreement and therefore both the employer and employee may act according to their wishes; union membership is not an issue when entering into the contract of employment.

7. Non-union shop: only workers who are not members of any labor organisation will be employed. Strictly speaking this is not a union security agreement but the denial of it; as a managerial policy non-union shop was achieved through the yellow dog contracts which now would constitute an unfair labor practice. ${ }^{164}$

All categories of union security agreements were held legal by the National Labor Relations Board, and the courts interpreting the proviso concluded that it protects not only closed and union shop but $a$ fortiori the milder forms of security arrangements. ${ }^{165}$ As a result of the widespread use of closed shop and union shop agreements compulsory unionism became a reality. The justification claimed for the aim of one hundred percent membership was that the labour organisation designated by majority vote as the bargaining representatives obtains benefits for all employees, including non-members, who accept them without being prepared to bear their share of the costs. Free riders were frowned upon.

\section{Abolition of Closed Shop}

Increasing anxiety over the powers of unions culminated in the enactment of the Taft-Hartley Act ${ }^{166}$ modifying those provisions of the

165 Id. 8. 8(a) (3), first proviso (only the most relevant words are quoted).

163 Public Service Co. of Colorado, (1950) 89 N.L.RB. 418; of. the agency shop agreement under the U.K. I.R. Act, 1971, supra, n. 4.

164 See Reynolds, Labour Economics and Labour Relations ch. 8; Maher, Labor and the Economy 159 et seq.

165 See Public Service Co. of Colorado. supra, n. 163; Algoma Plywood \& Veneer Co. v. Wisconsin Employ. ment Relations Board (1949) 336 U.S. 301 at 307, 93 L.Ed. 691, 69 Sup. Ct. 584 (maintenance membership).

100 The Labour Management Relations Act, 1947 (Taft-Hartley Act), Act of June 23, 1947, c. 120, 61 Stat. 136. 
Wagner Act which were thought to excessively favour labour. Section 8(3) was amended by adding the following new proviso: ${ }^{167}$

Provided further that no employer shall justify any discrimination against an employee for non-membership in a labor organisation

(A) if he has reasonable grounds for believing that such membership was not available to the employee on the same terms and conditions generally applicable to other members, or

(B) if he has reasonable grounds for believing that membership was denied or terminated for reasons other than the failure of the employee to tender the periodic dues and the initiation fees uniformly required as a condition of acquiring or retaining membership.

The effect of this amendment was the outlawing of the closed shop but not the union shop and other lesser union security agreements. The added proviso purported that employers would "still be permitted to enter into agreements requiring all employees in a given bargaining unit to become members thirty days after being hired," and that it should "remedy the most serious abuses of compulsory union membership and yet give employees and unions who feel that such agreements promoted stability by eliminating free riders the right to continue such arrangements." 168

Clause (B) signifies a momentous breakaway from the idea that union membership should be a prerequisite, or at least a collateral requirement, to obtaining and retaining a job. As a consequence expulsion from the union cannot be a ground for compulsory dismissal so long as the worker pays his membership dues. In the words of one learned writer "an employee can break every union rule in the book, be expelled from the union, and under the statute retain his job if he tenders his dues to the union." 169 In his view the statute aims at the separation of union membership and job rights. ${ }^{170}$

New Meaning of "Membership"

The Supreme Court, through White J., in N.L.R.B. v. General Motors Corporation ${ }^{171}$ expressed the view that the amendment not only abolished the closed shop but also altered the meaning of "membership" for the purposes of union security contracts. The learned Judge stated:172

Under the second proviso to $\mathrm{s}$. $8(\mathrm{a})(3)$, the burdens of membership upon which employment may be conditioned are expressly limited to the payment of initiation fees and monthly dues. It is permissible to condition employment upon membership, but membership, insofar as it has significance to employment rights, may in turn be conditioned only upon payment of fees and dues. "Membership" as a condition of employment is whittled down to its financial core.

During the first years after the amendments by the Taft-Hartley Act the interpretation of the second proviso appeared to be less clearcut. In the case of In re Union Starch Refining Co., ${ }^{173}$ where a security agreement required union membership as a condition of retaining employment and where three workers tendered the initiation fees and dues but refused to comply with the other duties of members, the National Labour

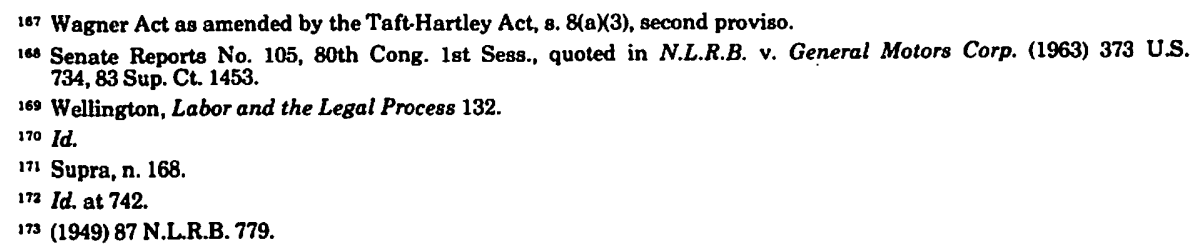


Relations Board held that their dismissal was not justified. The majority of the Board was of the opinion that by offering to pay the union dues the workers complied with the terms of the security agreement; therefore the construction placed on the proviso by the employer and the union to the effect that the workers' conduct amounted to refusal to become members was incorrect, as the mere tender of accrued fees and dues brought them within the protection of the section $8(a)(3)$ provisos and of section $8(b)(2)$. A dissenting opinion by two members held that membership must import more than "mere willingness to pay the organisation's dues and fees, and certainly encompasses a willingness to comply with reasonable formalities in the process of joining."174 The minority of the Board argued that no denial of membership could be asserted when the employees did not seek membership at all.

The profound change in the concept of union membership appears to have wholly erased the seemingly reasonable assertions put forward by the dissenters. Later the problem of full and limited membership was argued again before the Supreme Court in a somewhat different context. In the Allis Chalmers ${ }^{175}$ case the United Auto Workers Union fined some members for crossing the picket line during an official strike, and these workers complained to the N.L.R.B. of violation of their rights under section 7. The Board refused the complaint but the Court of Appeals upheld it on the grounds that under a union shop agreement membership is not a totally voluntary act, and therefore the union rules should not be given the binding force that rules of truly voluntary associations might have. ${ }^{176}$ The Supreme court by a five to four vote reversed the Court of Appeals. ${ }^{177}$ Justice Brennen in his dissenting opinion commented that the majority decision "makes it highly dangerous for an employee in a union shop to exercise his section 7 right to refrain from participating in a strike called by a union in which he is a member by name only."178

Closed shop agreements became legal again in the building industry by special provision in the Landrum-Griffin Act. ${ }^{179}$

\section{Union Hiring Halls}

Union shop agreements remained lawful. The method by which such agreements are carried out minimises the difference between the two sorts of security arrangements to the point where their effect can be regarded for all practical purposes to be the same. Under closed shop agreements the hiring of employees by the employer was done through the union which upon request sent the required number of workersusually, but not necessarily, the people from the top of the jobseekers' list. Naturally only union members' names could be placed on the register. This "hiring hall" or employment agency maintained by the union has been retained under the union shop agreements with the difference that all jobseekers who so desire, regardless of their union membership or the lack of it, must be enrolled in the register, and when

174 Id. at 792

173 Local 248, United Auto Workers (Allis Chalmers Mfg. Co.) (1964) 149 N.L.R.B. 67.

${ }^{176}$ Allis Chalmers Mfg. Co. v. N.L.R.B. (1966) 385 F. (2d) 565 (7th Cir.).

177 N.L.R.B. v. Allis Chalmers Mfg. Co. (1966) 385 U.S. 810, 17L. ed. (2d) 51, 87 Sup. Ct. 54, 65 L.R.R.M. 2449.

17n Id., 65 L.R.R.M. 2449 at 2465.

179 The Labour Management Reporting and Disclosure Act, 1959 (Landrum-Griffen Act), Act of Sept. 14, 1959, Public Law 86-257, 73 Stat. 519. 
available job opportunities are allocated they should be treated equally. It is an unfair labour practice for the union:180

to cause or attempt to cause an employer to discriminate against an employee in violation of subsection $(a)(3)$ or to discriminate against an employee with respect to whom membership in such organisation has been denied or terminated on some ground other than his failure to tender the periodic dues and the initiation fees uniformly required as a condition of acquiring or retaining membership.

However, under the circumstances prevailing in a union hiring hall, it is not easy, even with honesty and goodwill, to avoid situations which may appear to be discrimination. The workers are very rarely selected by the employer, or the employer's representative himself. Selection usually is by the union official charged with the managing of the employment bureau. The elimination of the potential illegality inherent in the exclusive hiring hall situation posed serious problems to the N.L.R.B. and the Courts. The Board succinctly emphasized the very contradiction between the existence of a union run employment agency and the statutory prohibition against discrimination in the case of Mountain Pacific: ${ }^{181}$

From the standpoint of the working force generally-those who, for all practical purposes, can obtain jobs only through the grace of the union or its officials-it is difficult to conceive of anything that would encourage their subservience to union activity, whatever its form, more than this kind of hiring hall arrangement. Faced with this hiring hall contract, applicants for employment may not ask themselves what skills, experiences, or virtues are likely to win them jobs . . . [T]heir concern is, and must be: What, about themselves, will probably please the unions or their agents? How can they conduct themselves best to conform with such rules and policies as unions are likely to enforce? In short, how to ingratiate themselves with the union, regardless of what the employer's desires or needs might be.

The proposed remedy-somewhat heavy handed-was that all dues collected in connection with an illegal hiring hall within a six month period prior to the filing of the complaint for unfair labour practice were to be returned to the employees. ${ }^{182}$ The Supreme Court, however, considered that such an order went beyond the Board's statutory powers and that the refund of dues had no relation to any proven offence. ${ }^{183}$ The primary declaration of the Board to the effect that the hiring hall position in a collective agreement would be held prima facie invalid unless it complied with certain requirements, was not challenged. The criteria to give an agreement an unequivocal non-discriminatory character are set out in three points: 184

(1) Selection of applicants for referral to jobs must not be based on, or affected by, union membership or any aspect of union rules, requirements or policies.

(2) The employer must retain the right to reject any applicant selected by the union.

(3) The parties to the agreements must make known by posting notices in customary

places all the provisions of the hiring agreement, including the above safeguards.

\section{Unprovable Motive}

Although this Mountain Pacific formula was followed in subsequent cases 185 in the view of a learned writer "the Board never really justified

\footnotetext{
180 Supra, n. 167, 8. 8(b)(2).

181 Mountain Pacific Chapter of the Associated General Contractors Inc. (1957) 119 N.L.R.B. 883 at 895.

182 This is the so-called Brown-Olds remedy; Plumbers and Pipefitters (Brown-Olds Plumbing \& Heating Co.) (1956) 115 N.L.R.B. 594.

${ }^{163}$ Local 60, United Bhd. of Carpenters \& Joiners v. N.L.R.B. (1961) 365 U.S. 651.

is Supra, n. 181 at 897.

18s E.8., Local 357, Teamsters v. N.L.R.B. (1961) 365 U.S. 667.
} 
its ... standards sufficiently to qualify them as rigid rules rather than general guides."186 The main criticism arises from the requirement of motive for the establishment of unfair labour practices: proof that discrimination was positively motivated by the wish to encourage union membership and not by an independent purpose. Such proof, it seems, was equated by the Board with mere inference from surrounding circumstances, and therefore it seems "highly improper to hold ... that a union and employer are guilty of unfair practices requiring proof of motive without ever attempting the proof."187

Thus the line between legal union shop involving a union-run hiring hall and an illegal security agreement implemented through a discriminatory employment agency, amounting in fact to a closed shop, has been drawn on the shadowy foundation of unprovable motive. The only effective remedy evolved by the Board, and approved by the Court of Appeals, seems to be the requirement of keeping records of the hiring hall operations and making them available to the N.L.R.B. regional director on request. ${ }^{188}$ It has been suggested the union be allowed to show that the discrimination was an isolated case; further that a veto be given to the Regional Director over hiring hall arrangements. ${ }^{189}$

A further remarkable effect of the union hiring hall arrangements coupled with the new concept of membership is the blurring of the dividing line between union shop and agency shop or contributory nonmembership. The understandable desire to union officials to encourage membership in their organisation, not necessarily appearing in the form of actual discrimination but causing a psychological fear of potential discrimination in the mind of the jobseekers, may in fact create a situation where agency shop becomes equivalent to union shop. And if job-applicants, who already belong to the union at the time of the selection, are given all or the best of employment opportunities, the prohibited closed shop reappears under the disguise of agency shop or union shop.

\section{Conscientious Objectors and Civil Rights}

The position of conscientious objectors does not carry the same importance as in New Zealand or in Britain in theory at least. Because of the difficulties arising from union hall arrangements discussed above, it may be necessary to file a complaint of unfair labour practices in order to exercise the right of abstention. 190

On the other hand the right to belong cannot be frustrated by the union on the ground claimed by voluntary organisations that they have a privilege to select their members. The Civil Rights Act, 1964 makes it an unfair labour practice for a labor organisation: ${ }^{191}$

(1) to exclude or to expel from its membership, or otherwise to discriminate against, any individual because of his race, color, religion, sex or national origin;

(2) to limit, segregate or classify its membership ... in any way which would deprive any individual of employment opportunities . . . because of . . race, color, religion, sex or national origin;

\footnotetext{
iss Wellington, supra, n. 169 at 140.

187 Id. at 141.

186 J.J. Hagerty (1962) 139 N.L.R.B. 633.

189 See for a detailed excellent analysis in depth on the problem on union security agreements, Wellington, supra, n. 169 at 131-144.

190 Religious objectors had to pay "support money" equivalent to dues: In the Matter of American Seating Co. 98 N.L.R.B. 800.

199 The Civil Rights Act, 1964, Act of July 2, 1964, Public Law, 78 stat. 241.
} 
(3) to cause, or attempt to cause, an employer to discriminate against an individual in violation of this section.

The practical application and enforcement of this section is intended to be safeguarded by two different procedures: first, the Equal Employment Opportunity Commission created by the Act endeavours to settle any wrong resulting from breach of the statute by negotiation and conciliation. ${ }^{192}$ If this is unsuccessful or if the settlement has not been observed, the complaint can be taken to the courts, which upon finding an unlawful employment practice may grant an injunction. ${ }^{193}$ In the course of the court hearing, no admission or statement made during the prior conciliatory negotiations before the Commssion can be used as evidence. ${ }^{194}$ The Attorney General, if he has reasonable cause to believe that a pattern or practice of resistance is systematically carried on by any person or group, has the power to intervene and to seek an injunction. ${ }^{195}$ Otherwise the aggrieved party himself must fight his case alone-this can be an unbearable financial burden for a man who obviously is out of work or at least not in the kind of employment he sought.

\section{CONCLUSIONS}

Upon examining the three systems of union security arrangements certain similarities and contrasts will emerge. First, it should be noted that both in New Zealand and great Britain voluntary registration by the workers' associations is required to bring them under the provisions of the relevant statutes. Labour organisations may function without being registered but the disadvantages of such existence serve as an inducement against it. In the United States the question does not arise, the legislation extends to, and binds, all trade unions.

Both the British and American legislation declares as basic principles the freedom of positive and negative association, the right to join or not to join, though in Britain non-registered trade unions are not quite on par with the registered ones as far as protection of this freedom is concerned. Interference with the workers' right in this respect constitutes unfair industrial practices on the Eastern, and unfair labour practices on the Western, side of the Atlantic. The respective statutes, however, permit certain kinds of union security agreements in both countries which in effect create compulsory unionism, at least to a limited extent. These arrangements must be regarded as exceptions to the fundamental concept of voluntariness in joining trade unions.

Contrariwise, it cannot be denied that in New Zealand the general rule is the compulsion to be a union member. Notwithstanding the repeal of the statutory provision making it mandatory to include in every award and industrial agreement a preference clause, by custom such clauses are invariably inserted, and the situation in fact has not been changed. The loophole which may have been left by the use of qualified preference clauses can be dismissed as negligible, as nearly all preference provisions are unqualified. The only practicable way out is by the difficult process of conscientious objection.

\footnotetext{
192 Id. s. 706(a).

193 Id. 8. 706(g), (k).

190 Id. 8. 706(a).

185 Id. 8. 707.
} 
Under the I.R. Act conscientious objection is possible in Britain for workers covered by approved closed shop or agency shop agreements. They are obliged to pay a sum, normally equivalent to union dues, to a certain charity. In New Zealand the amount of union fees must be paid into the consolidated fund.

Closed shop agreements are allowed in Britain if after scrutiny by the Industrial Relations Commission they have been approved by the National Industrial Relations Court. Only in exceptional circumstances will such approval be given, otherwise the parties should enter into an agency shop agreement under which in lieu of membership the worker is bound to contribute to the union the same amounts as members. Those who object to supporting a labour organisation of which they do not wish to be members may be exempted on conscientious grounds in the same manner as under a closed shop agreement.

In the United States closed shop agreements are prohibited now, except in the building industry, but union shop and agency shop agreements are legal. At this juncture it should be pointed out that in Britain the expressions "closed shop" and "union shop" are used interchangeably, unlike in America where the dividing line, in theory, if not in practice, is firmly drawn. The agency shop agreements in both countries created a new relationship between the union and the worker, the contributory non-member who pays the dues to the union in recognition of its bargaining activities for all the workers. The contributory nonmember in Britain should be clearly distinguished from the exempted worker: although in practice the latter has to pay the same amounts, on grounds of conscience he is allowed to support a charity instead of the union. The duty of paying dues without other obligations towards, and rights in, the union, on the other hand has led in the United States to a reassessment of the concept of membership evolving the class of limited members. Coupled with the "inherent illegality" of hiring hall arrangements the situation has developed where agency shop may be equal to union shop, and even union shop to the prohibited closed shop.

Is compulsory unionism compatible with the idea that trade unions are voluntary organisations? It has already been said that the trade union of today's advanced industrialised society has developed from a mere voluntary association into a quasi-public body fulfilling as essential function, a public utility "existing for the purpose of representing employees,"196 and has become "part of the social machinery of the state."197 While these statements contain much truth, unions, though they exercise a "quasi-public power"198 do not actually form part of the state machinery, at least not in Western democracies, but they are formative forces in society exercising a healthy social, economic and political pressure. To discharge their role as formative forces unions must retain a fair degree of independence. ${ }^{199}$

Compulsory unionism, as it has been shown, can be imposed by the state or by agreement between employees and unions. If it is the result of mandatory legislation unions need not fight for members-they merely collect the fees; as a consequence they lose their organising initiative,

\footnotetext{
196 Grodin, supra, n. 90 at 90.

197 Hutt, supra, n. 89 at 5.

183 Friedmann, Law in Changing Society 265 et seq.

109 See further, Kahn-Freund Law and Opinion in England in the Twentieth Century in Labour Law (ed. Ginsberg) 215, 223 et seq.; Cole, An Introduction to Trade Unionism 31 et seq.; Szakats, supra, n. 87, c. 1 and 2.
} 
diminish their activities, and become dependent on the state. State compulsion, in general, weakens the labour movement. "Compulsory unionism [does] not [make] unionists." 200

The introduction of a compulsory form of membership achieved as a result of employer-union agreements, in contrast, can be regarded as a voluntary security measure in the interest of the union and the majority of workers. Though "voluntary compulsion" may sound self-contradictory, the manifestation of the majority's will coupled with measures safeguarding the dissident minority's interests gives the expression a solid basis of reason. If these conditions are present, and the agreement is implemented with honesty, the overall requirement of trade union membership results from the labour organisation's own strength and popularity among the workers. While state imposed compulsory unionism creates weak unions, achieving the fullest possible membership by agreement signifies strength. ${ }^{201}$

200 Hare, supra, n. 45 at 197.

201 The British and American systems, with all their weaknesses, no doubt belong to the second category; the New Zealand preference clauses with the indelible imprint of the long statutory compulsion even after the purported abolition appear to have remained in the first, though it may be argued that as a result of customary consent to unqualified preference they would have moved nearer to the second. 